\title{
Clinical Evaluation of Root Canal Irrigants in Dogs
}

\author{
I. CAPÍK, S. ANDRAŠKOVÁ*, E. HOLODA*,V. LEDECKÝ \\ Clinic of Surgery, Orthopaedics and Radiology \\ Department of Microbiology* \\ University of Veterinary Medicine, Košice, Slovakia
}

Received August 6, 2004

Accepted March 3, 2005

\begin{abstract}
Capík I., S. Andrašková, E. Holoda, V. Ledecký: Clinical Evaluation of Root Canal Irrigants in Dogs. Acta vet. Brno, 2005, 74: 97-101.

Bacteria from infected root canals can invade dentinal tubules, thus dentin disinfection is an important aspect of endodontic therapy. The aim of this study was to evaluate the aerobic and anaerobic microflora contaminating tooth root canals of fractured teeth of dogs, the efficacy of mechanical root canal instrumentation and three endodontic irrigants used in $1 \%$ concentration.

Twenty nine fractured teeth (12 three-rooted, two double-rooted and 15 single-rooted) with exposure of pulp cavity for two to three months were used in this study. The root canal enlargement was done using $\mathrm{K}$-files and saline as rinsing solution until obtaining clean dentinal shavings. The clean dentinal shavings from the last $\mathrm{K}$-file used were immediately placed into a culture medium as the first sample. The infected canals were exposed to one of the irrigants (iodine, chlorhexidine, sodium hypochlorite) for three minutes. Saline solution served as a control. Viable bacteria recovered from the apical part of root canals were analyzed one months later.

Mechanical root canal instrumentation ensured complete removal of aerobic and anaerobic microorganisms from $36.4 \%$ and $10.9 \%$ of treated root canals, respectively. Both aerobic and anaerobic microorganisms were removed completely from $9.1 \%$ of root canals by mechanical instrumentation. Chlorhexidine showed the best disinfectant effect followed by iodine and sodium hypochlorite.
\end{abstract}

Dog, root canal, infection, irrigants, iodine, chlorhexidine, sodium hypochlorite

The majority of tooth fractures are accompanied by open pulp cavity and other associated complications. The inflammatory process, progressing via apical delta, results in periapical inflammation (Fichtel 2000; Pavlica 1990).

Root canal infections are multibacterial, mixed infections, dominated by anaerobic bacteria. Anaerobes seem to play an important role in the development and perpetuation of endodontic pathology. During the period of rapid periapical lesion expansion, the root canal microflora becomes increasingly anaerobic (Tani-Ishii et al. 1994).

The unsuccessful outcome of endodontic therapy has been related to persistent anaerobic infections.

A pulpal infection process of long duration allows bacteria to spread to the entire root canal system, including ramifications, isthmuses, apical deltas, and dentinal tubules. In vitro studies have attempted to show dentinal tubule penetration by a diverse spectrum of microorganisms (Perez et al. 1993; Drake et al. 1994). Nevertheless, obligate anaerobic bacterial species that are frequently associated with endodontic diseases were not used in these studies.

Human dentinal tubules are invaded by two obligate anaerobes and two facultative anaerobic bacteria (Akpata and Blechman 1982). In vitro root canal dentinal tubule invasion by selected anaerobic bacteria commonly isolated from endodontic infections indicated that all bacterial strains tested were able to penetrate into dentinal tubules, but to different extents (Siqueira et al. 1996).

Address for correspondence:

MVDr. Igor Capík

Clinic of Surgeny, Orthopaedics and Radiology

University of Veterinary Medicine

Komenského 73

04181 Košice, Slovakia

Phone: +421 556337832

Fax: +421556 337832

E-mail:capik@uvm.sk

http://www.vfu.cz/acta-vet/actavet.htm 
Many researchers believe that bacterial invasion from the exposed dentinal surface into the dentinal tubules is less extensive in vital teeth than in the nonvital ones, because vital teeth have live odontoblastic processes and supporting collagen fibres within the tubules that direct the flow of dentinal fluid through the dentinal tubules from the pulp at a constant pressure.

The success of endodontic treatment depends on the dentist's ability to clean and disinfect the complex canal system three-dimensionally, and then to fill and seal this space completely. Shaping of the canal opens this space to the action of an irrigant. Important reqiurements on the endodontic irrigant include properties such as antimicrobial activity, tissue-dissolving capability, and non-toxicity to periapical tissues (Cohen and Burns 1999). NaOCl has been considered the best up-to-date canal irrigant. The action of $\mathrm{NaOCl}$ as an antibacterial agent and solvent of organic substances has peaked at a concentration of $5.25 \%$. A pilot study showed that commonly used root canal irrigants permeate completely through the dentinal tubules within the midsection of roots. However, the effectiveness of the irrigant depended largely upon the type of bacteria present within the tubules (Buck et al. 1999). Ringel et al. (1982) postulated that reinfection of endodontically treated teeth can occur from bacteria residing within apical tubules and also from bacteria introduced into the canal during the treatment.

\section{Materials and Methods}

The study was carried out on 29 fractured teeth (12 three-rooted, 2 double-rooted and 15 single-rooted) with infected roots. All teeth involved in this study had a history of tooth crown fractures, two-to-three-month-old. All teeth had necrotic dental pulps. The age of dogs involved in this study ranged from three to five years.

After preparation of access to cavity, the working length was determined radiologically and root canal enlargement was done using K-files until clean dentinal shavings were obtained. During this procedure the root canals were rinsed with neutral saline solution which did not affect root canal contamination. This allowed to evaluate the efficacy of mechanical instrumentation as one step of endodontic treatment.

The clean dentinal shavings from the last K-file used (only from apical third) were immediatelly placed into the culture medium as the first sample.

Composition of the culture medium:

1/ Anaerobe Basal Agar-oxid with the use of "Gas Pack" (Oxoid) to create anaerobic conditions - for anaerobes.

2/ Blood agar and Endo agar - for aerobes.

The cultures were incubated at $37^{\circ} \mathrm{C}$ for 48 hours.

After collection of samples the roots were randomly divided into four groups:

- group $1(\mathrm{n}=12)$ - roots were treated with $10 \mathrm{ml}$ saline, dried, and restored using composite material

- group $2(\mathrm{n}=16)$ - roots were disinfected with $1 \%$ chlorhexidine (Nolvasan)

- group $3(\mathrm{n}=13)$ - roots were disinfected with $1 \%$ sodium hypochlorite (Parcan)

- group $4(\mathrm{n}=14)$ - roots were disinfected using $1 \%$ iodine (Betadine)

Despite the different concentrations of active ingredients in commercial preparations to ensure the same conditions during the experiment the root canal irrigants were applied at the same time and at the same concentration.

The canals were irrigated using $6 \mathrm{ml}$ of irrigant slowly flushing them for three minutes using a 25 gauge needle and $10 \mathrm{ml}$ syringe. After disinfection the root canals were flushed with $10 \mathrm{ml}$ of saline solution, dried with sterile paper points and sealed with composite resin (Valux Plus 3M) wihout root canal obturation.

The same sampling procedure was used one month later after flushing the root canals with saline solution to compare the efficiency of different root canal disinfectants. The dentinal shavings were again taken from the apical third of root canals and examined microbiologicaly.

The principal aim of this study was to investigate the efficiency of mechanical instrumentation on the prevalence of microorganisms in the apical third of root canals. Secondly the composition of aerobic an anaerobic microflora; in the apical third of root canals in crown tooth fractures two-to-three-month-old was assessed after mechanical instrumentation. Finally, the efficiency of the three mentioned root canal disinfectants was compared with regard to devitalization of microflora determined by culture.

\section{Results}

A minimal K-file size N-20 was used at the begining of mechanical instrumentation and maximal K-file size $\mathrm{N}-60$ at the end of this procedure. The mean initial and final K-file sizes were $\mathrm{N}-30$ and $\mathrm{N}-50$, respectively.

Collection of samples after root canal instrumentation revealed the following: 
1/ Aerobes were detected in 38 root canals following mechanical instrumentation $(69.1 \%)$. Streptococcus spp. was the mostly frequently recovered aerobe contaminating the root canals (42.1\%). Staphylococcus epidermidis and Neisseria pharyngis contaminated root canals at $34.2 \%$ cases.

2/ Anaerobic contamination of rot canals was substituted with Bacillus spp. (B. megaterium, B. mycoides, B. polymyxa, B. licheniformis, B. coagulans, B. brevis, B. popilie) $69.4 \%$, Bacteroides spp. (B. cappilosus, B. oris, B. intermedius) $65.3 \%$, Peptostreptococcus $46.9 \%$, and Peptococcus $14.3 \%$.

Table 1 shows the aerobes and anaerobes recovered from the apical thirds of root canals of fractured teeth.

Table 1. Microbial contamination of the apical thirds of root canals

\begin{tabular}{|l|l|}
\hline Aerobes & Anaerobes \\
\hline Streptococcus (nonhaemolytic, viridans) & Peptostreptococcus \\
\hline Staphylococcus epidermidis & $\begin{array}{l}\text { Bacillus spp. (megaterium, popilie } \\
\text { Licheniformis, polymyxa, mycoides, coagulans, brevis) }\end{array}$ \\
\hline Neisseria pharyngis & Bacteroides spp. (cappilosus, intermedius, oris) \\
\hline & Peptococcus \\
\hline
\end{tabular}

Mechanical root canal instrumentation ensured complete removal of aerobic microorganisms from 20 root canals (36.4\%) and of anaerobic microorganisms from 6 root canals $(10.9 \%)$. Aerobes and anaerobes were completely absent in five root canals following mechanical instrumentation $(9.1 \%)$.

Table 2 compares the efficiency of different disinfectants in devitalization of root canal microflora when used in $1 \%$ concentration.

Table 2 . Efficiency of disinfectant against microbes in root canals

\begin{tabular}{|l|rr|rr|rr|c|c|}
\hline $\begin{array}{l}\text { Disinfectant/ } \\
\text { antimicrobial } \\
\text { efficiency }\end{array}$ & \multicolumn{2}{|c|}{$\begin{array}{c}1 \% \\
\text { chlorhexidine }\end{array}$} & \multicolumn{1}{|c|}{$1 \%$ iodine } & $\begin{array}{c}1 \% \text { sodium } \\
\text { hypochlorite }\end{array}$ & $\begin{array}{c}\text { Saline } \\
\text { solution }\end{array}$ \\
\hline Aerobes & $7 / 4$ & $57.1 \%$ & $11 / 6$ & $54.5 \%$ & $10 / 3$ & $30.0 \%$ & $7 / 1$ & $14.3 \%$ \\
\hline Anaerobes & $12 / 5$ & $41.7 \%$ & $13 / 4$ & $30.1 \%$ & $13 / 3$ & $23.1 \%$ & $11 / 0$ & $0 \%$ \\
\hline Aerobes + anaerobes & $6 / 3$ & $50.0 \%$ & $11 / 2$ & $18.2 \%$ & $10 / 1$ & $10.0 \%$ & $11 / 0$ & $0 \%$ \\
\hline
\end{tabular}

Positive before disinfection / negative 1 month later

Table 3

\begin{tabular}{|l|c|c|c|c|c|}
\hline $\begin{array}{l}\text { Disinfectant/ } \\
\text { Negative } \\
\text { samples }\end{array}$ & $\begin{array}{c}1 \% \\
\text { chlorhexidine }\end{array}$ & $1 \%$ iodine & $\begin{array}{c}1 \% \text { sodium } \\
\text { hypochlorite }\end{array}$ & $\begin{array}{c}\text { Saline } \\
\text { solution }\end{array}$ & $\begin{array}{c}\text { Total root } \\
\text { number }\end{array}$ \\
\hline $\begin{array}{l}\text { Total number } \\
\text { of treated roots }\end{array}$ & 16 & 14 & 13 & 12 & 55 \\
\hline Before disinfect. & $9 / 4$ & $3 / 1$ & $3 / 0$ & $5 / 1$ & $20 / 6$ \\
\hline 1 month later & $11 / 9$ & $9 / 5$ & $6 / 3$ & $5 / 1$ & $31 / 18$ \\
\hline
\end{tabular}

Aerobes / anaerobes

\section{Discussion}

The purpose of endodontic treatment of teeth with pulpal necrosis and apical periodontitis is the maximum elimination of microorganisms from the root canal system, dentinal tubules, and periapical region. This is achieved mainly by biomechanical preparation complemented by an intracanal medication (Siquiera Jr et al. 1996). It is important to examine the 
sterility of a root canal before obturation. For this purpose, a bacteriological examination is usually done. Many investigators have suggested that the smear layer adhering to the enlarged canal wall might have a harmful effect on the healing response in the infected tooth (Myers et al. 1969; Seltzer et al. 1963). Studies related to the smear layer confirmed that eliminating this layer was the most useful procedure in producing a sterile environment in the root canal (Takakazu et al. 1995). They confirmed a significant influence of alternative irrigation using $5 \% \mathrm{Na} \mathrm{OCl}$ and $3 \% \mathrm{H}_{2} \mathrm{O}_{2}$ during root canal enlargement. Finally, the treated teeth were irrigated using $15 \%$ EDTA or saline solution. The results showed a high proportion of negative cultures in both groups ( $81.4 \%$ and $75 \%$, respectively). On the other hand, the number of negative cultures found within 1 month decreased in both groups later, though the decrease was significant only in the group using saline.

Our results showed $36.4 \%$ efficacy of mechanical root canal treatment against aerobic contamination and $10.9 \%$ efficacy against anaerobic root canal contamination in teeth fractured two to three months before treatment.

According to our results chlorhexidine was the most effective root canal disinfectant $(50 \%$ efficacy) followed by iodine (18.2\%) and hypochlorite $(10 \%)$.

One issue frequently debated in recent years is whether conscientious cleaning by instrumentation and irrigation reduces the number of bacteria to a point where the obturation of the canal at the same visit will ensure successful treatment. Many practicioners feel that high success rates are possible with this technique based on patient acceptance, lack of significant flare-ups, and practice management considerations (S oltan off 1978). Because the current research findings indicate that one-step treatment of teeth with apical periodontitis is obturation of an infected canal in a relatively high percentage of cases, proponents of this technique rely on the lack of nutrition and space for bacterial multiplication to overcome the bacterial infection. Matsumiya and Kitamura (1960) suggested that entombment of bacteria will result in their death, even though in their study the canals were obturated with $\mathrm{Ca}(\mathrm{OH})_{2}$, an effective antibacterial agent, and it was not clear if the bacteria were viable or not.

Our results did not confirm the previous assertions related to the role of a smear layer in the persistence of root canal infection. None of the negative roots in our study showed presence of contamination one month after mechanical instrumentation. Similar results were obtained by other workers. Among twenty negative roots, contamination was confirmed only in two roots when examined one month later.

The number of negative cultures did not significantly increase in aerobic root canal contamination. It may result from unsuitable microenvironment related to permanent sealing of access cavity and an anaerobic growth creating anaerobic conditions.

These results were achieved without root canal obturation, which may suggest less important role of root canal obturation in dogs. This may be explaned by anatomical apical structure. Completely developed canine root apex consists of a series of small openings referred to as an apical delta. Lateral or accesory canals are uncommon in dogs and cats in comparison with humans. These anatomical features contribute to minimal communication between the root canal and periapical tissue acting as a natural barier in rapid extension of root canal contamination to periapical tissues.

In our opinion, on the basis of results obtained in this study, the conscientious cleaning by instrumentation and irrigation may ensure successful treatment regardless of root canal obturation in cases when the root canal has been exposed to oral microflora for two to three months. Out of five negative root canals investigated after mechanical instrumentation and irrigation without subsequent root canal obturation, the aerobic contamination (nonhaemolytic streptococcus) was diagnosed only in one root at the second appointment (one months after the initial treatment). No anaerobes were detected in those roots. 


\section{Klinické vyhodnotenie účinnosti troch koreňových irigantov u psov}

Pri zlomeninách zubov s otvorenou dreňovou dutinou dochádza ku kontaminácii nielen samotnej dreňovej dutiny, koreňového kanála ale aj dentínových tubulov. Adekvátna dezinfekcia počas endodontickej terapie preto zohráva jednu z významných úloh úspešnej liečby. Úlohou tejto práce bolo posúdit zastúpenie aeróbnej a anaeróbnej mikroflóry kontaminujúcej koreňové kanály, účinnost̉ mechanického opracovania koreňových kanálov a účinnost troch endodontických irigantov použitých v $1 \%$ koncentrácii. V práci bolo použitých 55 koreňových kanálov klinických pacientov. Časový interval ošetrenia od vzniku fraktúry zuba bol v rozmedzí 2-3 mesiace. Mechanické opracovanie koreňového kanála bolo vykonané použitím Kerrových endodontických pilníčkov a vyplachovaním endodontického systému fyziologickým roztokom. Senzoricky čisté dentínové piliny z apikálnej tretiny koreňového kanála boli hned' vložené do kultivačného média ako prvá vzorka. Infikované koreňové kanály boli vystavené pôsobeniu jedného z testovaných irigantov (chlorhexidín, jód, chlornan sodný) po dobu troch minút. Skupina koreňových kanálov vyplachovaných fyziologickým roztokom slúžila ako kontrola. Ošetrené zuby boli zapečatené kompozitom bez predchádzajúcej obturácie. Po uplynutí jedného mesiaca boli znova otvorené, vypláchnuté fyziologickým roztokom a z apikálnej tertiny odobraté vzorky na opätovné mikrobiologické vyšetrenie.

Mechanické opracovanie koreňových kanálov nepotvrdilo mikrobiologickým vyšetrením aeróbnu kontamináciu u 36,4\% a anaeróbnu kontamináciu u 10,9\% koreňových kanálov.

Mikrobiologickým vyšetrením nebola potvrdená aeróbna aj anaeróbna kontaminácia u 9,1\% ošetrených koreňových kanálov. Najlepšie dezinfekčné účinky boli zistené pri použití chlorhexidínu, následne jódu a chlornanu sódneho.

\section{References}

AKPATA ES, BLECHMAN, H 1982: Bacterial invasion of pulpal dentine wall in vitro. J Dent Res 61: 425-428

BUCK RA, ELEAZER PD, STAAT RH 1999: In vitro disinfection of dentinal tubules by various endodontic irrigants. J Endodon 25: 786-788

COHEN S, BURNS RC 1994 : Pathawys of the pulp. $6^{\text {th }}$ ed. St Louis: CV Mosby.pp 183-199

DRAKE DR, WIEMANN AH, RIVERA EM, WALTON RE 1994: Bacterial retention in canal walls in vitro: effect of smear layer. J Endodon 20: 78-82

FICHTEL T 2000: Periapical granuloma of upper canine. Veterinářství 6: 228-229

MATSUMIYA S, KITAMURA, M 1960: Histopatological and histobacteriological studies of the relation between the condition of sterilization of the interior of the root canal and the healing process of periapical tissues in experimentally infected root canals. Bull Tokyo Dental Coll 1: 1-19

MYERS JW, MARSHALL FJ, ROSEN S 1969: The incidence and identity of microorganisms present in root canals at filling following culture reversals. Oral Surg 28: 889-896

OLIET S 1983: Single-visit endodontics: a clinical study. J Endodon 9: 4-7

PAVLICA Z 1990: Some possibilities in reconstruction of injured canines in dogs. In: Proceedings of 25. meeting of specialists in surgery, orthopaedics and radiology. Prague 1990: 63-8

PEREZ F, CALAS P, FALGUEROLLES A, MAURETTE A 1993: Migration of Streptococus sanguis strain through the root dentinal tubules. J Endodon 19: 297-301

RINGEL AM, PATTERSON SS, NEWTON CW, MILLER CH, MUHLERN JM 1982: In vivo evaluation of chlorhexidine gluconate solution and sodium hypochlorite solution as root canal irrigants. J Endodon 8: 200-204

SELTZER S, BENDER IB, TRUKENKOPF S 1963: Factors affecting successful repair after root canal therapy. J Am Dent Assoc 67: 651-62

SIQUEIRA JF, DE UZEDA M, FONSECA MEF 1996: A scanning electron microscopic evaluation of in vitro dentinal tubules penetration by selected anaerobic bacteria. J Endodon 22: 308-310

SOLTANOFF W 1978: A comparative study of the single-visit and the multiple-visit endodontic procedure. J Endodon 4: 9-14

TAKAKAZU, Y et al. 1995: Clinical evaluation of the efficacy of solution as an endodontic irrigant. J Endodon 21: $592-593$

TANI-ISHII N, WANG C-T, TANNER A, STASHENKO P 1994: Changes in root canal microbiota during the development of rat periapical lesions. Oral Microbiol Immunol 9: 129-35 